\title{
AOR
}

Selected Papers of \#AolR2019:

The $20^{\text {th }}$ Annual Conference of the Association of Internet Researchers Brisbane, Australia / 2-5 October 2019

\section{TRUSTING TWITTERSPHERE AS A GENUINE POLITICAL DEBATE? THE CASE OF INDONESIAN ELECTION HASHTAGS}

\author{
Yearry Panji Setianto \\ Department of Communication Studies, Sultan Ageng Tirtayasa University
}

\begin{abstract}
This research in progress explores how political discussion on Indonesian Twittersphere could provide a genuine conversation on debates related to the upcoming 2019 national election in Indonesia. Taking the case of the presidential and parliamentary election in the upcoming April 2019, the author uses social media data on Twitter to investigate whether the discussions are heavily lean into digital public sphere or more dominated by political buzzer and bots. The author examines this by creating Twitter network maps based on hashtags related to the election. Most of the hashtags analyzed could attract hundreds of small communities, created mini-publics, which in turn shows the degree of willingness of the Indonesian social media users to participate in this practice of digital citizenship. Qualitative observations on the selection of the most significant actors within the network and the words they posted are employed to understand if the conversations were not led by either dominant political actors or political buzzers/bots, and thus, suggest the citizens' honest form of political communication. Despite the limitations of studying Twitter data, the author suggests that by taking a closer attention to how political conversation in non-English/Western political environment, this study might provide valuable insights on the development of genuine utilization of (and trust on) the social media platforms for political engagement.
\end{abstract}

Key words: online politics, elections, Indonesia, Twittersphere, social network analysis

Suggested Citation (APA): Setianto, Y. (2019, October 2-5). Trusting Twittersphere as a Genuine Political Debate? The Case of Indonesian Election Hashtags. Paper presented at AolR 2019: The $20^{\text {th }}$ Annual Conference of the Association of Internet Researchers. Brisbane, Australia: AolR. Retrieved from http://spir.aoir.org. 


\section{Research Background}

Indonesia is the most Muslim populous country and the third largest democracy in the world. For this reason, scholars study the democratization process in this country, which gradually shifted from its three decades of Suharto's authoritarian period to the more politically open environment during the reformation era in 1998 (Aspinall, 2014; Liddle, 1985). Yet, many aware that not only the last election in 2014 became the most divided political momentum for Indonesian politics-where a civilian Joko Widodo (or Jokowi) won over a former general and Suharto's in-law Prabowo Subianto. Both candidates are re-running for the 2019 presidential election, contributing to the more divided society. The tension between the two opposing parties are more heated within the digital political sphere, especially when the supporters of both candidates regularly creating various hashtags to promote their interest. Using this background, this paper aims to further investigate $(R Q)$ to what extent that online political discussion on Twitter can be considered as a genuine form of political expression within the context of the 2019 Indonesian national election?

The Internet was one of the determinants of the collapse of the Suharto's regime in 1998. Through the online circulation of foreign news, analysis and tutorials on organizing mass demonstration via mailing list Apakabar-moderated in the United States and its content was provided by Indonesian dissents, the internet offered unexpected political power to ordinary citizens to oppose the authoritarian regime (Hill \& Sen, 2000).

Following Suharto's downfall, the Indonesian society are enjoying a free political environment and little control from the government to the digital sphere. On various occasions, Indonesians are relying upon online and social media to perform their digital citizenship. Nevertheless, Lim's (2013) study shows how Indonesian social media users tend to engage in digital political activity only and being reluctant in joining any political movement offline. This does not mean that online political affairs could not influence real-life politics. When Jakarta's Governor Basuki Tjahaja Utama or Ahok's political speech on YouTube was edited and resulted in the accusation of blasphemy against Islam, many online protests among Indonesian Muslims had turned into massive rallies demanding a trial for Ahok.

The study of social media use for political purposes has becoming more common. Notably started with the study of the United States' 2008 Presidential Election (Larsson \& Moe, 2012), many scholars are interested in examining how Twitter is used to amplify political messages by political parties/candidates, the publics, or events (Bruns \& Highfield, 2013; Burgess \& Bruns, 2012; Elmer, 2013). Jungherr (2016) found that there are at least 127 research on Twitter and political campaign published in various Englishbased academic publications but only one study uses Indonesian politics as the research context. This shows that little attention given by scholars to non-English political context on the study of Twitter, especially on the use of hashtags related to election. 


\section{Method}

The author follows hashtags related to the 2019 Indonesian presidential election campaign, mainly four months before the election (on April 2019). Here, the author will only include the analysis of three major hashtags: \#DebatPilpres2019 (meaning: the 2019 presidential election debate), \#ShutDownJokowi and \#UninstallBukalapak (uninstall an Indonesian e-commerce platform Bukalapak since its CEO was said to be Prabowo's supporter). Data is retrieved trough Twitter's public API using NodeXL software several hours following the hashtag became a trending topic. Using this method, the author could obtain around 18,000 Tweets per hashtags. The network of tweets is visualized using Gephi to identify the interactions and communities.

\section{Analysis}

Surrounding the event of second presidential candidate debates on February 17, 2019 there were at least 116,000 tweets posted using hashtag \#DebatPilpres2019 which include 11.814 nodes with 23.484 edges. Using modularity feature, 1.2666 clusters or online community within the networks are identified (Figure 1).

Figure 1.

The Network of \#DebatePilpres2019

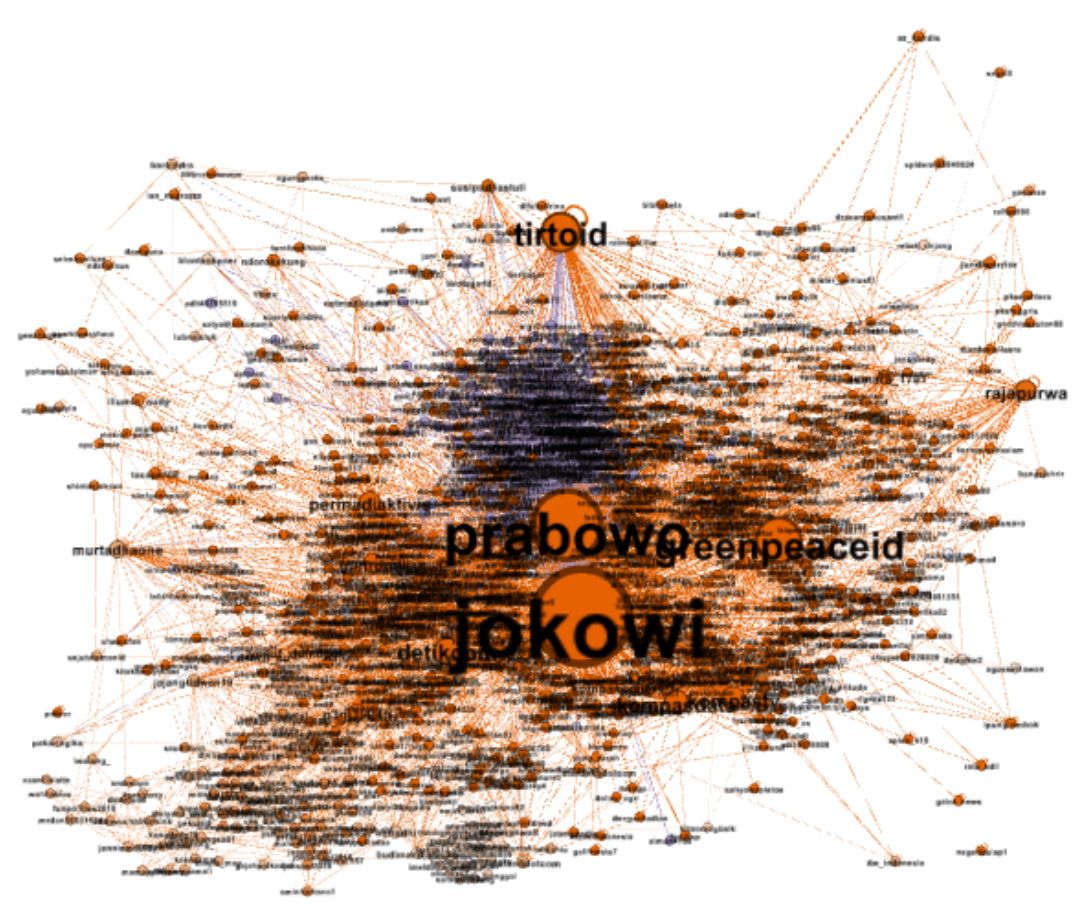

The overall of the structure of the network is heavily relied on two presidential candidates @jokowi and @prabowo (with 2,883 and 1993 in-degree connections respectively) accounts, whereas @greenpeaceid (the Greenpeace Indonesia's Twitter account with 1178 in-degree connections) came to the surface only because the topic of debate was about environment. However, it can be argued that the importance of @greenpeaceid within the network also reflects the nature of the conversation where many of the tweets posted tried to exhibit a more rational argument by bringing/mentioning the environment issue within their posts. Interestingly, several 
national media organizations' accounts are found to be visible on the conversationmeaning that they are still being used as major reference by the Indonesian netizens while they are talking about the political debate.

On the second hashtag, \#ShutDownJokowi the use of tweets tends to be more associated with Prabowo's supporters who use their messages to attack Jokowi. For instance, Twitter accounts like @marierteman and @anonlokal are found to be two most significant actors within the network (based on the network's degree calculation); who are also frequently posts tweets using similar/related hashtags supporting Prabowo. Interestingly, the second largest community identified is quite distance with the first group-it is worth mentioning that this community is led by @rokhmatlabib from Hizbut Tahrir Indonesia (Islamist radical group) (Figure 2).

Figure 2.

The Network of \#ShutDownJokowi

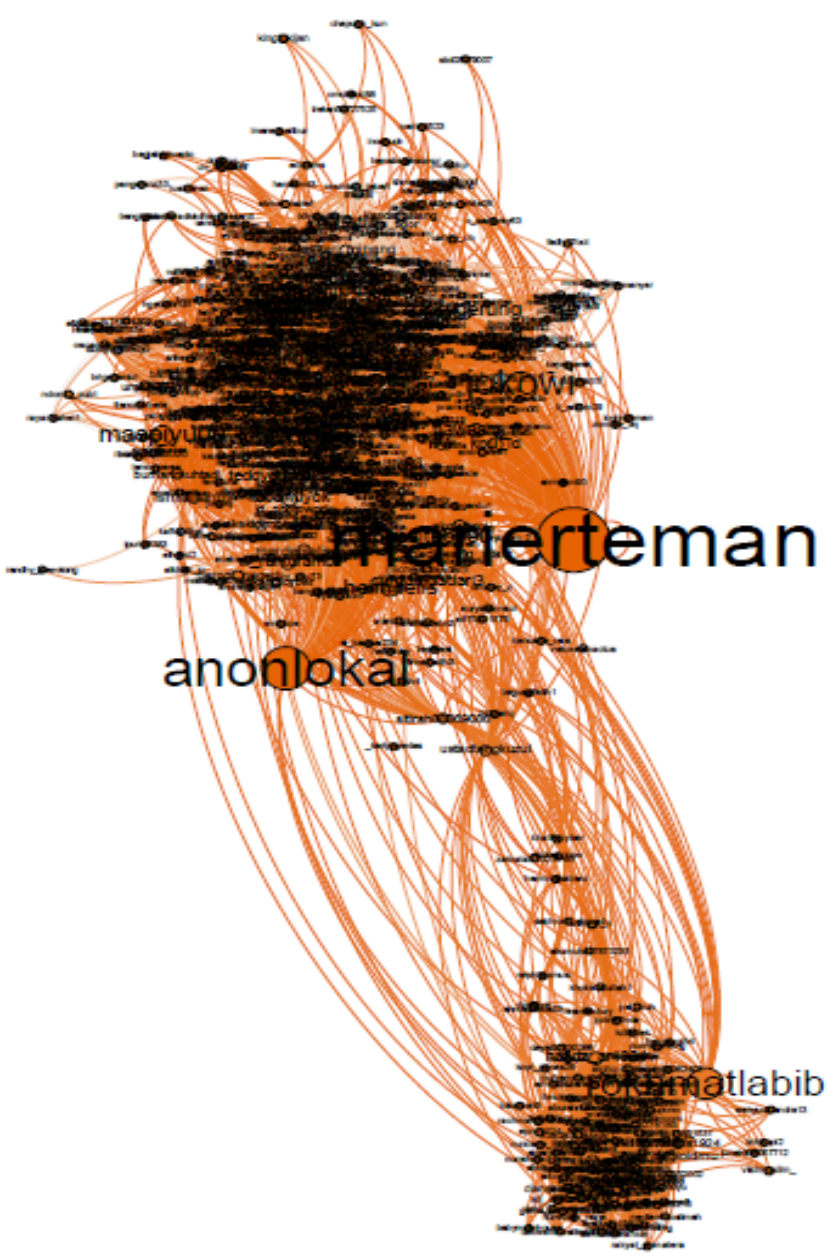

On contrary, on the third hashtag \#UninstallBukalapak, Jokowi's supporters attack @bukalapak and its CEO @achmadzaki (Figure 3). Overall, while both hashtags are mainly used as a negative campaign tools against each opposing candidate, the messages posted on Twitter are mostly organic, meaning they are not posted by bots; 
although there are some cases where the posts came from political buzzers or Prabowo's and Jokowi's hardliners. This practice indicates that many of both-side of the supporters are collaborating, trusting each other in delivering the same political messages in criticizing their political enemies.

Figure 3.

The Network of \#UninstallBukalapak

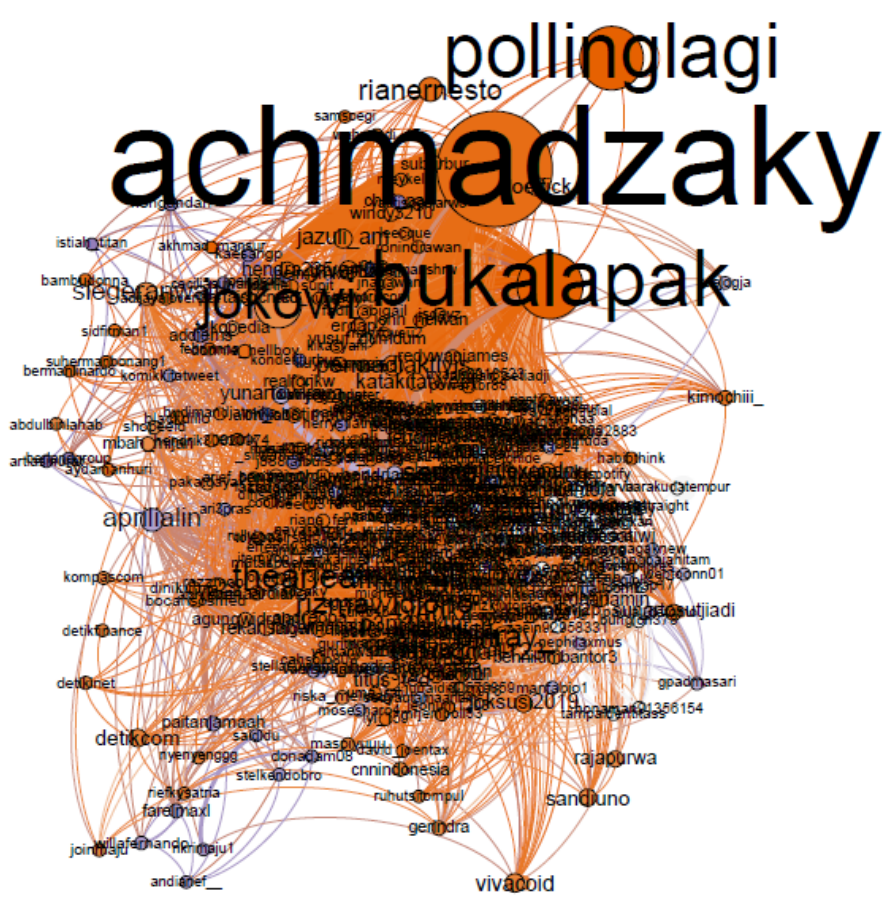

In addition, while Tweets that came from political buzzers are visible in those hashtags, there is little evidence that the conversation became skewed toward the messages that were initiated by them. Also, the activity of political bots (identified both using Botomoter application as well as a qualitative closer examination whether the account is 'human' or bot through its activity on a certain period of time) has been limited throughout the analyzed hashtags. By taking these into consideration, the author suggests that there is a higher chance that the Indonesian social media users are still eager to articulate their political opinion on Twitter since they are still trusting that this platform could offer 'genuine' conversation on various national political issues.

\section{Conclusion}

Taken the examples from these three hashtags, it is evident that the Indonesian netizens are still eager to participate in political talks on Twitter, either to support their political leaders or to criticize the opponents. The involvement of numerous accounts on various election-related issues/hashtags also indicates citizens' level of trust in using the platform, engaging with other users, mentioning and referring to media organizations accounts. One of the reasons, the author argues, is that not many tweets 
on the networks came from bots or political buzzers but genuinely came from the supporters and ordinary citizens. Indeed, a longer observation (for months, or year perhaps) and more in-depth qualitative analysis on more diverse hashtags should better evaluate whether this argument is consistent within the case of Indonesian political sphere on Twitter.

\section{References}

Aspinall, E. (2014). Indonesian politics in 2014: Democracy's close call. Bulletin of Indonesian Economic Studies, 50(3), 347-369.

Bruns, A., \& Highfield, T. (2013). Political networks on Twitter: Tweeting the Queensland state election. Information, Communication \& Society, 16(5), 667-691.

Burgess, J., \& Bruns, A. (2012). (Not) the Twitter election: The dynamics of the \#ausvotes conversation in relation to the Australian media ecology. Journalism Practice, 6(3), 384-402.

Elmer, G. (2013). Live research: Twittering an election debate. New Media \& Society, 15(1), 18-30.

Hill, D. T. \& Sen, K. (2000). The internet in Indonesia's new democracy. Democratization, 7(1), 119-136.

Jungherr, A. (2016). Twitter use in political campaigns: A systematic literature review. Journal of Information Technology \& Politics, 13(1), 72-91.

Larsson, A. O. \& Moe, H. (2011). Studying political microblogging: Twitter users in the 2010 Swedish election campaign. New Media \& Society, 5, 729-747.

Liddle, R. W. (1985). Suharto's Indonesia: Personal rule and political institution. Pacific Affairs, 58(1), 68-90.

Lim, M. (2013). Many clicks but little sticks: Social media activism in Indonesia. Journal of Contemporary Asia, 43(4), 636-657. 